\title{
Tracing the Origin of Groundwater Nitrate in an Area Affected by Acid Rain Using Dual Isotopic Composition of Nitrate
}

\author{
Tianming Huang $\mathbb{D}^{1,2,3,4}$ Zhenbin $\mathrm{Li}^{1,2,3}$ Baoqiang $\mathrm{Ma}^{1,5}$ and Yin Long ${ }^{1,2,3}$ \\ ${ }^{1}$ Key Laboratory of Shale Gas and Geoengineering, Institute of Geology and Geophysics, Chinese Academy of Sciences, \\ Beijing 100029, China \\ ${ }^{2}$ College of Earth and Planetary Sciences, University of Chinese Academy of Sciences, Beijing 100049, China \\ ${ }^{3}$ Innovation Academy for Earth Science, Chinese Academy of Sciences, Beijing 100029, China \\ ${ }^{4}$ Department of Geoscience, University of Calgary, Calgary, Alberta, Canada T2N 1N4 \\ ${ }^{5}$ College of Geoscience and Surveying Engineering, China University of Mining \& Technology, Beijing 100083, China
}

Correspondence should be addressed to Tianming Huang; tmhuang@mail.iggcas.ac.cn

Received 7 September 2019; Revised 8 November 2019; Accepted 15 November 2019; Published 29 November 2019

Academic Editor: Jean-Luc Michelot

Copyright ( $) 2019$ Tianming Huang et al. This is an open access article distributed under the Creative Commons Attribution License, which permits unrestricted use, distribution, and reproduction in any medium, provided the original work is properly cited.

\begin{abstract}
Acid rain with a relatively high concentration of ammonium and nitrate can accelerate rock weathering. However, its impact on groundwater nitrate is uncertain. This study evaluated the dual isotopic composition of nitrate $\left(\delta^{15} \mathrm{~N}_{-} \mathrm{NO}_{3}{ }^{-}\right.$and $\left.\delta^{18} \mathrm{O}_{-} \mathrm{NO}_{3}{ }^{-}\right)$ from precipitation to groundwater in a rural mountainous area affected by acid rain. The average concentration for $\mathrm{NH}_{4}^{+}$is $1.25 \mathrm{mg} / \mathrm{L}$ and $\mathrm{NO}_{3}{ }^{-}$is $2.59 \mathrm{mg} / \mathrm{L}$ of acid rain. Groundwater $\mathrm{NO}_{3}{ }^{-}$concentrations ranged from $<0.05$ to $11.8 \mathrm{mg} / \mathrm{L}$ (baseline), and $\mathrm{NH}_{4}{ }^{+}$concentrations ranged from 0.06 to $0.28 \mathrm{mg} / \mathrm{L}$. The results show that groundwater $\delta^{18} \mathrm{O}-\mathrm{NO}_{3}{ }^{-}$values $(-4.7 \%$ o to $+4.2 \%$ ) were lower than the values of rainfall $\delta^{18} \mathrm{O}_{-} \mathrm{NO}_{3}{ }^{-}\left(+24.9 \%\right.$ o to $+67.3 \%$ ) , suggesting that rainfall $\mathrm{NO}_{3}{ }^{-}$contributes little to groundwater $\mathrm{NO}_{3}{ }^{-}$. Groundwater $\delta^{15} \mathrm{~N}_{-\mathrm{NO}_{3}}^{-}$values $\left(+0.1 \%\right.$ o to $+7.5 \%$ o) were higher than the values of $\delta^{15} \mathrm{~N}_{-} \mathrm{NO}_{3}{ }^{-}$derived from the nitrification of rainfall $\mathrm{NH}_{4}^{+}$(less than $-4.7 \%$ in the study area), suggesting that nitrification of rainfall $\mathrm{NH}_{4}^{+}$also contributes little to groundwater $\mathrm{NO}_{3}{ }^{-}$. This implies that rainfall $\mathrm{NO}_{3}{ }^{-}$and $\mathrm{NH}_{4}{ }^{+}$have been utilized. The dual isotopic composition of nitrate shows that baseline groundwater $\mathrm{NO}_{3}{ }^{-}$is derived mainly from nitrification of soil nitrogen. The denitrification process is limited in the groundwater system. This study shows that the rainfall $\mathrm{NO}_{3}{ }^{-}$and $\mathrm{NH}_{4}{ }^{+}$contribute little to groundwater $\mathrm{NO}_{3}{ }^{-}$, improving the understanding of the nitrogen cycle in areas with a high concentration of $\mathrm{NH}_{4}^{+}$and $\mathrm{NO}_{3}{ }^{-}$ in rainfall.
\end{abstract}

\section{Introduction}

Since the beginning of the twentieth century, the atmospheric concentration of acidic gases, such as $\mathrm{SO}_{2}, \mathrm{NO}_{\mathrm{x}}$, and $\mathrm{NH}_{3}$ which are mainly a result of industrial activity and coal burning has increased steadily [1-4]. Consequently, there were large depositions of atmospheric acid in parts of Europe, North America, and SW China. Sulfur and nitrogen concentrations and deposition in North America and Europe have declined significantly due to emission reduction policies [5]. In the last 40 years, the southwest and southeast parts of
China have witnessed varying degrees of acid rain (rainfall with $\mathrm{pH}$ value lower than 5.6 is defined as acid rain) [6-9]. Based on the "China Environmental Status Bulletin in 2014", released by the Ministry of Environmental Protection [8], $44 \%$ of 470 cities witnessed acid rainfall and rainfall in $30 \%$ of cities had an annual average $\mathrm{pH}$ lower than 5.6.

Acid rain has a high concentration of $\mathrm{NH}_{4}{ }^{+}$and $\mathrm{NO}_{3}{ }^{-}$ $[8,9]$. During recharge to a river or groundwater system, $\mathrm{NH}_{4}{ }^{+}$is nitrified into $\mathrm{NO}_{3}{ }^{-}$under oxidative conditions [10]. As two protons worth of acidity are produced for every $\mathrm{NH}_{4}{ }^{+}$to form $\mathrm{NO}_{3}{ }^{-}$during nitrification, this process 
tends to make the environment more acidic [11-13]. An acidic environment accelerates rock weathering, irrespective of the source of $\mathrm{NH}_{4}^{+}$either nitrogen fertilizers [14] or rainfall [15].

Increased inputs of anthropogenic nitrogen could lead to excess nitrogen in ecosystems [16]. The development of new agricultural practices to satisfy a growing global demand for food has led to extensive eutrophication of freshwaters and coastal zones [17]. In order to prevent methemoglobinemia, the maximum contaminant level for nitrate in drinking water has been set at $50 \mathrm{mg} / \mathrm{L}$ as $\mathrm{NO}_{3}{ }^{-}$by the World Health Organization [18] and $10 \mathrm{mg} / \mathrm{L}$ as $\mathrm{NO}_{3}{ }^{-} \mathrm{N}$ by the United States Environmental Protection Agency and National Health Commission of the People's Republic of China (in this study, the concentration of nitrate is expressed as $\mathrm{NO}_{3}{ }^{-}$). As nitrogen is a reactive element in ecosystems [1], a series of reactions and processes control nitrogen dynamics in the soil and groundwater. These processes, which include assimilation, nitrification, denitrification, volatilization, sorption/desorption, and consumption by plants, significantly influence groundwater nitrate $[19,20]$.

Previous studies focused mainly on the sources of river/groundwater nitrate using multiple environmental tracers, such as the dual isotopic composition of nitrate $\left(\delta^{15} \mathrm{~N}-\mathrm{NO}_{3}{ }^{-}\right.$and $\left.\delta^{18} \mathrm{O}-\mathrm{NO}_{3}{ }^{-}\right)$and the nitrogen isotope of ammonium $\left(\delta^{15} \mathrm{~N}-\mathrm{NH}_{4}{ }^{+}\right)$. For example, the ranges of isotopic compositions of nitrate suggested that the major sources of nitrate in the large Changjiang (Yangtze) River come from modified fertilizer and urban sewage effluent [21]. Wastewater was found to be the main source of nitrate contamination in urban areas [22]. The nitrate input from rainfall to groundwater is often neglected, but nitrification is generally regarded as a prerequisite for nitrate leaching [23]. However, few studies on estimating groundwater nitrate concentrations accounted for atmospheric deposition of nitrogen [24-26]. Furthermore, the mixing model of the dual isotopic composition of nitrate $\left(\delta^{15} \mathrm{~N}-\mathrm{NO}_{3}{ }^{-}\right.$and $\left.\delta^{18} \mathrm{O}-\mathrm{NO}_{3}{ }^{-}\right)$revealed that the nitrate from atmospheric deposition contributed $3 \%$ of the river nitrate in a river subbasin in Mecklenburg-Vorpommern (Germany) [27]. This proportion was found to be $30 \%$ for direct $\mathrm{NO}_{3}{ }^{-}$input to spring water from rainfall in northeast Bavaria (Germany) without any microbial interaction [23]; here, the $\delta^{18} \mathrm{O}-\mathrm{NO}_{3}{ }^{-}$values for spring water range from $+11 \%$ o to $+33 \%$. Therefore, the impact of $\mathrm{NH}_{4}{ }^{+}$and $\mathrm{NO}_{3}{ }^{-}$in rainfall on groundwater systems remains uncertain.

This study aims to assess the potential input of nitrate from acid rain using chemical and isotopic data of rainfall and groundwater in a rural mountainous area in SW China. The results would have important implications for the groundwater nitrogen cycle in areas with a high concentration of rain ammonium and assessment of the baseline level of nitrate related to nitrate contamination due to anthropogenic activities.

\section{Study Area}

The study area is located in the northern Xishui County $\left(25^{\circ} 06^{\prime} 35^{\prime \prime}-28^{\circ} 50^{\prime} 15^{\prime \prime} \mathrm{N}\right.$ and $\left.105^{\circ} 50^{\prime} 20^{\prime \prime}-106^{\circ} 44^{\prime} 30^{\prime \prime} \mathrm{E}\right)$,
Zunyi, Guizhou Province, SW China. It has an average annual temperature of $13.1^{\circ} \mathrm{C}$ and average annual precipitation of $1138 \mathrm{~mm}$. The study area is a mountainous area with elevation ranging from $750 \mathrm{~m}$ to $1700 \mathrm{~m}$ a.s.l. (Figure 1 ). The Xishui River flows into the Yangtze River. The land use/land cover (LULC) in Xishui County is mainly forest (62\%) and farmland (31\%) [28]. The study area has different lithologies from carbonates to silicates, and therefore, it is an ideal site to assess the impact of lithologies on nitrate concentration.

The study area tectonically belongs to the transitional zone between the northern part of the Central Guizhou Uplift and the southeastern part of the Sichuan Basin [29]. The sampling site is in the northwestern limb of the Sangmuchang anticline (Figure 1). The oldest stratum exposed at the core of the anticline is the Proterozoic dolomite rock. The stratum layers from old to new (from the core to northwestern) are Cambrian, Ordovician, Silurian, Permian, Triassic, Jurassic, and Cretaceous [30]. Shallow groundwater aquifers in the study area can be divided into four types (Figure 1) based on lithology and water abundance [31]: (I) fracturecave water occurring mainly in carbonate rock (limestone and dolomite), (II) cave-fracture water generally occurring in shale with little limestone (discharge of springs of $0.1-$ $10 \mathrm{~L} / \mathrm{s}$ ), (III) pore-fracture water only occurring in the Triassic sandstone with a relatively rich yield of $25-125 \mathrm{~m}^{3}$ per day per meter for a well, and (IV) fracture water occurring in sandstone and mudstone with a groundwater runoff modulus of less than $2 \mathrm{~L} \mathrm{~s}^{-1} \mathrm{~km}^{-2}$. The varying lithology and strong anisotropy of shallow aquifers means that shallow groundwater in the study area generally emerges in the form of springs and shows heterogeneity due to the mixing of various geochemical components.

The population is relatively sparse in the area, and people mainly live in towns and lowland areas. In the mountainous areas (main sampling area), the population is even more sparely distributed. There are almost no wells in the study area; therefore, spring waters are sampled at different stratum. Some of these springs are used for distributed domestic water supply (one or more families use one spring).

\section{Sampling and Analysis}

A total of 23 samples were collected in 2018 from spring flowing from different types of aquifers. The locations of the sampling points are shown in Figure 1. Physical and chemical parameters such as electrical conductivity (EC), $\mathrm{pH}$, oxidation-reduction potential (ORP), and temperature were measured in situ using a multiparameter device (Hach HQ40d). The titration of $\mathrm{HCO}_{3}{ }^{-}$and $\mathrm{CO}_{3}{ }^{2-}$ was conducted on site using a 16900 Digital Titrator (Hach) with $0.8 \mathrm{~mol} / \mathrm{L}$ sulfuric acid for titration and phenolphthalein and methyl orange as indicators. Samples used for cation $\left(\mathrm{Na}^{+}, \mathrm{K}^{+}\right.$, $\mathrm{Ca}^{2+}, \mathrm{Mg}^{2+}$, and $\mathrm{Sr}^{2+}$ ) analysis were immediately acidified with distilled $\mathrm{HNO}_{3}(1 \mathrm{~mol} / \mathrm{L})$ to a $\mathrm{pH}$ of less than 2. The anions, $\mathrm{Cl}^{-}, \mathrm{SO}_{4}{ }^{2-}, \mathrm{NO}_{3}{ }^{-}$, and $\mathrm{F}^{-}$, were analyzed by ion chromatography (ICS-1100), and the cations, $\mathrm{Na}^{+}, \mathrm{K}^{+}, \mathrm{Ca}^{2+}$, and $\mathrm{Mg}^{2+}$, were analyzed using inductively coupled plasma optical emission spectrometry (ICP-OES) at the Beijing Research Institute of Uranium Geology (BRIUG). The trace 


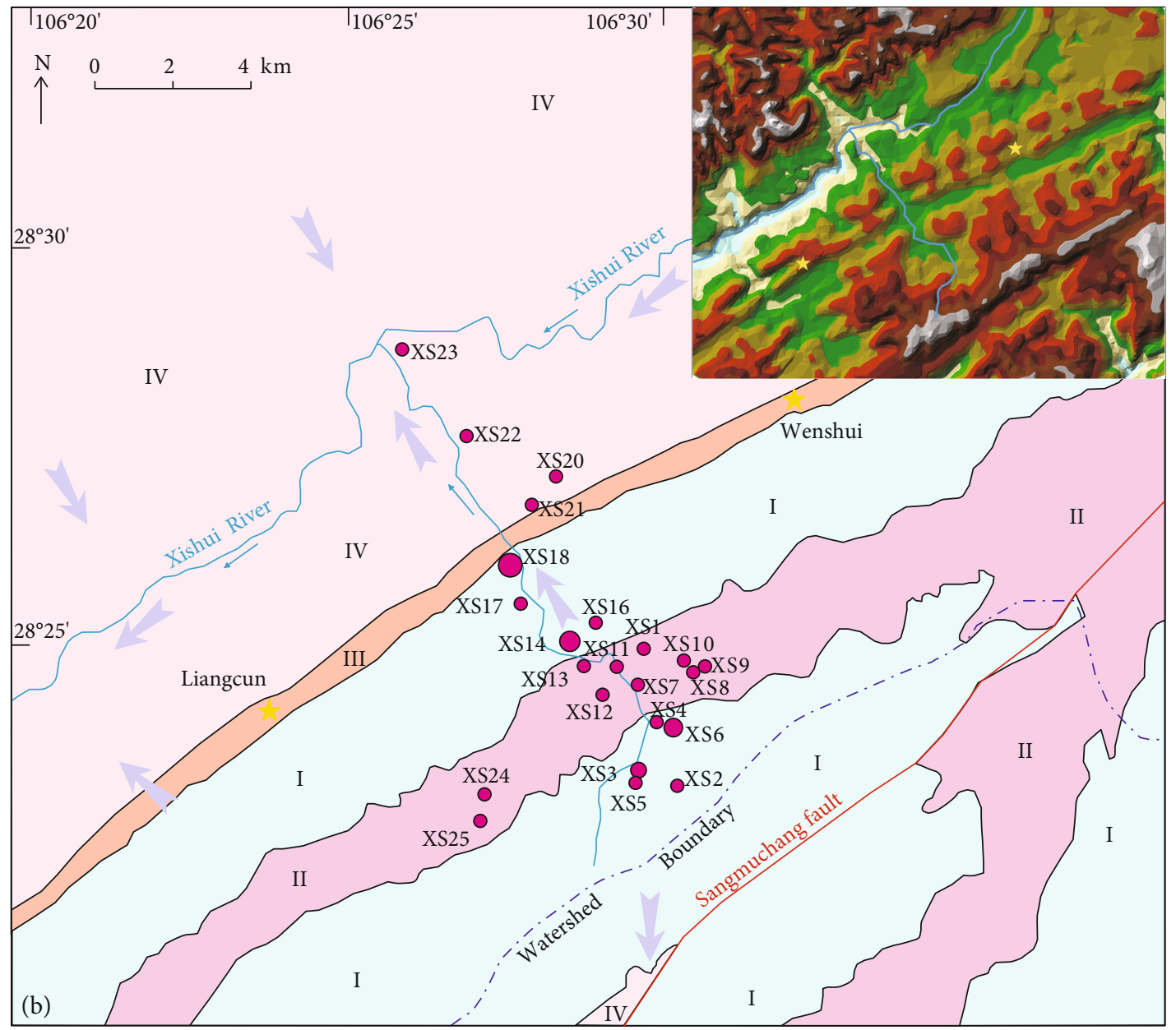

Aquifer type
I $\square$ II
Spring sample
$\Rightarrow$ Ground water flow direction
$\longrightarrow$ Surface water flow direction

Figure 1: Study area. (a) Topography with the lowest elevation of $750 \mathrm{~m}$ a.s.l. and the highest elevation of $1700 \mathrm{~m}$ a.s.l.; (b) aquifer types (the introduction can be found in the text), groundwater and surface water flow direction, and spring sampling sites. The bigger dots indicate the spring samples with higher discharges.

element $\mathrm{Sr}^{2+}$ was analyzed using inductively coupled plasma mass spectrometry (ICP-MS). $\mathrm{NH}_{4}{ }^{+}$and $\mathrm{NO}_{2}{ }^{-}$were measured using ultraviolet-visible spectroscopy, based on the methods of the GB/T 5750.6 standard, with a detection limit of $0.02 \mathrm{mg} / \mathrm{L}$ and $0.002 \mathrm{mg} / \mathrm{L}$. The charge balance errors for all groundwater samples ranged from $-1.1 \%$ to $4.8 \%$ and were within $\pm 5 \%$.

The water stable isotopes were measured at the Institute of Geology and Geophysics, Chinese Academy of Sciences (IGG-CAS) using a Picarro L1102-i isotopic water liquid analyzer. The results were reported in the form of $\delta^{2} \mathrm{H}$ and $\delta^{18} \mathrm{O} \quad\left(\delta=\left(R_{\text {sample }} / R_{\text {standard }}-1\right) \times 1,000\right)$ using the Vienna standard mean ocean water (VSMOW) as the reference. The analytical precision was $0.5 \%$ o for $\delta^{2} \mathrm{H}$ and $0.1 \%$ o for $\delta^{18} \mathrm{O}$. The ${ }^{87} \mathrm{Sr} /{ }^{86} \mathrm{Sr}$ ratio was measured at BRIUG using a Finnigan MAT 261 multiple collector thermal ionization mass spectrometer (MC-TIMS). Analysis of the NIST NBS
987 standard resulted in a ratio of $0.710235 \pm 0.000026$. The groundwater $\mathrm{N}$ and $\mathrm{O}$ isotopes in $\mathrm{NO}_{3}{ }^{-}$were measured via the denitrifier method $[32,33]$ at the Isotope Bioscience Laboratory, Faculty of Bioscience Engineering, Ghent University, Belgium, where $\mathrm{NO}_{3}{ }^{-}$was converted to $\mathrm{N}_{2} \mathrm{O}$ by denitrifying bacteria Pseudomonas aureofaciens. The results were reported in the form of $\delta^{15} \mathrm{~N}_{-} \mathrm{NO}_{3}{ }^{-}$and $\delta^{18} \mathrm{O}-\mathrm{NO}_{3}{ }^{-}$ using air (atmospheric nitrogen) and VSMOW as the standards. The analytical precisions for both $\delta^{15} \mathrm{~N}_{-} \mathrm{NO}_{3}{ }^{-}$and $\delta^{18} \mathrm{O}-\mathrm{NO}_{3}{ }^{-}$were both better than $0.5 \%$.

\section{Results and Discussion}

4.1. Geochemical and Isotopic Composition of Rainfall. No systematic observation data is available for rainfall in the study area. The Jinyunshan precipitation observation station managed by the Acid Deposition Monitoring Network in 
TABLE 1: Chemical composition of rainfall for Jinyunshan (JYS) from 2002 to 2017 [9], Zunyi (ZY) from 2002 to 2006 [34, 35], Guilin (GL) in 2010 [38], and Guiyang (GY) from 2003 to 2009 [36, 37, 40]. The unit for precipitation (Preci) is $\mathrm{mm} / \mathrm{yr}$ and the unit for concentration is $\mathrm{mg} / \mathrm{L}$.

\begin{tabular}{|c|c|c|c|c|c|c|c|c|c|c|c|c|}
\hline Year & Location & Preci & $\mathrm{pH}$ & $\mathrm{SO}_{4}{ }^{2-}$ & $\mathrm{NO}_{3}^{-}$ & $\mathrm{Cl}^{-}$ & $\mathrm{NH}_{4}^{+}$ & $\mathrm{Na}^{+}$ & $\mathrm{K}^{+}$ & $\mathrm{Ca}^{2+}$ & $\mathrm{Mg}^{2+}$ & $\mathrm{H}^{+}$ \\
\hline \multirow{2}{*}{2002} & JYS & 1607 & 4.18 & 7.521 & 1.825 & 0.459 & 1.502 & 0.136 & 0.402 & 1.189 & 0.081 & 0.044 \\
\hline & ZY & 1226 & 4.37 & 10.42 & 0.700 & & 1.920 & & & 1.980 & & \\
\hline \multirow{3}{*}{2003} & JYS & 1233 & 4.36 & 7.986 & 2.136 & 0.364 & 1.541 & 0.115 & 0.336 & 1.228 & 0.069 & 0.050 \\
\hline & ZY & 949 & 4.25 & 11.730 & 2.790 & & 3.040 & & & 1.970 & & \\
\hline & GY & & & & 2.259 & & 1.041 & & & & & \\
\hline \multirow{2}{*}{2004} & JYS & 1518 & 4.30 & 10.490 & 2.283 & 0.455 & 1.892 & 0.283 & 0.457 & 2.819 & 0.085 & 0.026 \\
\hline & ZY & 1111 & 4.28 & 13.750 & 1.600 & & 2.070 & & & 0.670 & & \\
\hline \multirow{3}{*}{2005} & JYS & 1461 & 4.59 & 9.784 & 2.131 & 0.549 & 1.895 & 0.352 & 0.443 & 2.308 & 0.076 & 0.024 \\
\hline & ZY & & 4.79 & & & & & & & & & \\
\hline & GY & & 4.74 & & & & & & & & & \\
\hline \multirow{3}{*}{2006} & JYS & 1196 & 4.63 & 13.530 & 2.860 & 0.482 & 2.183 & 0.153 & 0.444 & 3.932 & 0.096 & 0.020 \\
\hline & ZY & & 4.30 & & & & & & & & & \\
\hline & GY & & 4.35 & & & & & & & & & \\
\hline \multirow{2}{*}{2007} & JYS & 1645 & 4.69 & 8.676 & 1.951 & 0.309 & 1.353 & 0.143 & 0.264 & 2.205 & 0.067 & 0.030 \\
\hline & GY & & 4.44 & & & & & & & & & \\
\hline 2008 & JYS & 1213 & 4.52 & 11.540 & 2.880 & 0.545 & 1.778 & 0.237 & 0.372 & 2.733 & 0.111 & 0.044 \\
\hline \multirow{2}{*}{2009} & JYS & 1098 & 4.33 & 10.910 & 3.370 & 0.573 & 1.976 & 0.177 & 0.340 & 2.667 & 0.133 & 0.047 \\
\hline & GY & 1107 & 4.23 & 25.500 & 0.453 & 0.736 & 2.030 & 0.320 & 0.375 & 7.316 & 0.252 & 0.059 \\
\hline \multirow{2}{*}{2010} & JYS & 979 & 3.94 & 14.540 & 4.648 & 0.570 & 2.230 & 0.188 & 0.404 & 2.749 & 0.138 & 0.115 \\
\hline & GL & 1950 & 4.83 & 16.760 & 3.728 & 0.815 & 1.653 & 0.359 & 0.364 & 4.374 & 0.287 & 0.015 \\
\hline 2011 & JYS & 848 & 4.04 & 13.510 & 4.807 & 0.423 & 2.097 & 0.141 & 0.405 & 2.603 & 0.147 & 0.091 \\
\hline 2012 & JYS & 1006 & 4.09 & 11.930 & 4.366 & 0.413 & 2.234 & 0.144 & 0.298 & 2.367 & 0.140 & 0.082 \\
\hline 2013 & JYS & 1127 & 4.20 & 7.814 & 3.293 & 0.256 & 1.621 & 0.090 & 0.214 & 1.246 & 0.106 & 0.063 \\
\hline 2014 & JYS & 1490 & 4.39 & 5.796 & 2.827 & 0.202 & 1.271 & 0.103 & 0.172 & 1.041 & 0.105 & 0.041 \\
\hline 2015 & JYS & 1288 & 4.70 & 4.214 & 2.258 & 0.181 & 1.126 & 0.051 & 0.133 & 0.869 & 0.078 & 0.020 \\
\hline 2016 & JYS & 1217 & 4.97 & 3.836 & 2.323 & 0.168 & 1.184 & 0.059 & 0.131 & 1.522 & 0.093 & 0.011 \\
\hline 2017 & JYS & 1268 & 5.15 & 3.508 & 2.284 & 0.190 & 1.080 & 0.068 & 0.140 & 2.077 & 0.114 & 0.007 \\
\hline
\end{tabular}

East Asia has long-term observation data. The station $\left(106^{\circ} 22^{\prime} \mathrm{E}\right.$ and $\left.29^{\circ} 49^{\prime} \mathrm{N}\right)$ is located in Beibei District, Chongqing [9], about $40 \mathrm{~km}$ from the urban area of Chongqing. Jinyunshan forms one of the Natural Protection Region of Chongqing. The altitude of the Jinyunshan Mountain is about $700-900 \mathrm{~m}$ a.s.l., and the summit is at $952 \mathrm{~m}$ a.s.l. The physiognomy is typical low mountains. The climate in Jinyunshan is suitable for the growth of diversified plants due to high precipitation and high humidity of air and soil. The dominant plants consist of evergreen vegetation with a stable structure. As a Natural Protection Region, there are no industries, and only a few farming houses. Since this station, which is about $150 \mathrm{~km}$ far away from the study area, is situated in a rural site, it represents a rural district that is less impacted by anthropogenic activities than urban areas [9], similar to the study area. These areas experience acid rain with a similar pattern [8]. Therefore, the chemical composi- tion of rainfall in Jinyunshan was used to represent the chemical characteristics of precipitation in the study area. The chemical compositions of rainfall over whole regions affected by acid rain in SW China are all similar, such as Zunyi [34, 35], Guiyang [36], and Guilin [37, 38] (Table 1). Unfortunately, there is no data on dry deposition. Therefore, only wet deposition was considered in this study.

As the water cycle is relatively short for spring water, rainfall data from 2013 to 2017 was used. Systematic observations of rainfall chemical composition show that the $\mathrm{pH}$ values ranged from 4.20 to 5.15 from 2013 to 2017 (Table 1) with a weighted average of 4.55 , indicating the presence of acid rain. The main anions (in meq/L) are $\mathrm{SO}_{4}{ }^{2-}$ $(69 \%)$ and $\mathrm{NO}_{3}^{-}(27 \%)$, and the main cations are $\mathrm{Ca}^{2+}$ (39\%), $\mathrm{NH}_{4}^{+}(37 \%)$, and $\mathrm{H}^{+}(16 \%)$ (Figure 2). The $\mathrm{NO}_{3}{ }^{-}$ and $\mathrm{NH}_{4}{ }^{+}$concentrations showed limited variation, with averages of $2.59 \mathrm{mg} / \mathrm{L}$ and $1.25 \mathrm{mg} / \mathrm{L}$, respectively. The total 




Figure 2: Precipitation ion compositions (\% in meq/L). The ion compositions are the weighted average values from Jinyunshan, Beibei District, Chongqing, from 2013 to 2017. $\mathrm{SO}_{4}{ }^{2-}, \mathrm{NO}_{3}{ }^{-}, \mathrm{Ca}^{2+}$, $\mathrm{NH}_{4}{ }^{+}$, and $\mathrm{H}^{+}$are the main ions in precipitation (>15\%). The data are from [9].

inorganic nitrogen from atmospheric wet deposition is expected to be $17.7 \mathrm{~kg} \mathrm{Nha}^{-1} \mathrm{yr}^{-1}$, similar to the value of $18.4 \mathrm{~kg} \mathrm{Nha}^{-1} \mathrm{yr}^{-1}$ from southern Ontario, Canada, from 1980 to 1985 [24].

Previous studies have shown that the $\delta^{15} \mathrm{~N}-\mathrm{NO}_{3}{ }^{-}$of rainfall in Guiyang (about $190 \mathrm{~km}$ from the study area) ranges from $-12.7 \%$ to $+15.8 \%$ [39-42] with averages value of $-1.9 \%$ [39], $+1.5 \%$ [ [40], $+2.3 \%$ [ [41], and $+3.1 \%$ [ [42] during different sampling periods. The $\delta^{18} \mathrm{O}-\mathrm{NO}_{3}{ }^{-}$of rainfall ranges from $+25.2 \%$ o to $+40.1 \%$ with an average of $+34.2 \%$ [ [40]. In the Shapingba District, Chongqing (about $140 \mathrm{~km}$ from the study area, and close to the Jinyunshan station), $\delta^{15} \mathrm{~N}-\mathrm{NO}_{3}{ }^{-}$values range from $-1.0 \%$ o to $+6.9 \%$ with an average of $+1.5 \%$ and those of $\delta^{18} \mathrm{O}-\mathrm{NO}_{3}{ }^{-}$ranged from $+24.9 \%$ o to $+67.3 \%$ with an average of $+43.6 \%$ o (unpublished data from Dr. Pingheng Yang from Southwest University, China).

The $\delta^{15} \mathrm{~N}-\mathrm{NH}_{4}{ }^{+}$of rainfall in Guiyang ranged from $-28.7 \%$ o to $+7.8 \%$ o $[39,40]$ with average values of $-10.6 \%$ o and $-4.7 \%$ during different observation periods. In Chongqing, the value ranged from $-8.6 \%$ o to $+1.3 \%$ o [43] with an average of $-6.7 \%$.

The rainfall around the study area is similar to other global studies with respect to $\delta^{15} \mathrm{~N}-\mathrm{NO}_{3}{ }^{-}, \delta^{18} \mathrm{O}-\mathrm{NO}_{3}{ }^{-}$, and $\delta^{15} \mathrm{~N}-\mathrm{NH}_{4}{ }^{+}[44,45]$, and the average values are within the typical range, suggesting that they are important endmembers with which to trace the origin of $\mathrm{NO}_{3}{ }^{-}$in springs in the study area.

4.2. Water Chemistry and Isotopic Composition of Springs. The data for major ions, $\mathrm{pH}$, and stable isotopic composition for spring water are shown in Tables 2 and 3. The $\mathrm{pH}$ values of spring water ranged from 6.39 to 8.29 , with an average of 7.61, which is mostly neutral to slightly alkaline. The total dissolved solids (TDS) ranged from $53 \mathrm{mg} / \mathrm{L}$ to $368 \mathrm{mg} / \mathrm{L}(\mathrm{XS} 21$ of $16 \mathrm{mg} / \mathrm{L}$ is not included), with an average value of $210 \mathrm{mg} / \mathrm{L}$. The $\mathrm{Na}^{+}(0.1-6.8 \mathrm{mg} / \mathrm{L})$ and $\mathrm{Cl}^{-}(0.4-$ $7.6 \mathrm{mg} / \mathrm{L})$ concentrations were extremely low, with median values of 1.4 and $1.3 \mathrm{mg} / \mathrm{L}$, respectably. The Piper plot (Figure 3) shows that the main water types were $\mathrm{HCO}_{3}^{-}$$\mathrm{Ca}^{2+}, \quad \mathrm{HCO}_{3}{ }^{-}-\mathrm{Ca}^{2+} \cdot \mathrm{Mg}^{2+}$, and $\mathrm{HCO}_{3}{ }^{-} \cdot \mathrm{SO}_{4}{ }^{2-}-\mathrm{Ca}^{2+} \cdot \mathrm{Mg}^{2+}$ (\%meq/L $>10 \%$ is named). Some of the water types were $\mathrm{HCO}_{3}{ }^{-} \cdot \mathrm{SO}_{4}{ }^{2-}-\mathrm{Ca}^{2+} \cdot \mathrm{Mg}^{2+} \cdot \mathrm{Na}^{+}$(XS21 and XS22), and the corresponding strata are the Triassic and Jurassic sandstone, siltstone, mudstone, and shale. The TDS were mainly composed of $\mathrm{HCO}_{3}{ }^{-}\left(R^{2}\right.$ of 0.84 for TDS and $\left.\mathrm{HCO}_{3}{ }^{-}\right)$and $\mathrm{Ca}^{2+}+\mathrm{Mg}^{2+}\left(R^{2}\right.$ of 0.98 for TDS and $\left.\mathrm{Ca}^{2+}+\mathrm{Mg}^{2+}\right)$.

The spring water in the study area corresponds to the local meteoric water line (LMWL) of $\delta^{2} \mathrm{H}=7.89 \delta^{18} \mathrm{O}+$ 11.95 for Zunyi, obtained from the GNIP database [46], compared with the global meteoric water line (GMWL) of $\delta^{2} \mathrm{H}=8 \delta^{18} \mathrm{O}+10$ [47]. The difference in water stable isotopic composition for springs was mainly caused by recharge altitude. At higher altitudes, where the average temperatures are lower, precipitation will be isotopically depleted and for $\delta^{18} \mathrm{O}$, the depletion varies between about $-0.15 \%$ and $-0.5 \%$ per $100 \mathrm{~m}$ rise in altitude [48]. The outcrops of springs with most depleted isotopic values $\left(\delta^{18} \mathrm{O}\right.$ less than $-8 \%$, XS2, 3, and 5$)$ are located in the Cambrian carbonates with the highest altitudes within all samples, and the outcrop of spring with most enriched isotopic value $\left(\delta^{18} \mathrm{O}\right.$ of $-6.1 \%$ ) was located in lower altitudes (Figures 1 and 4 ).

However, in the higher altitudes, the groundwater samples were found to deviate from the LMWL (Figure 4). The deuterium excess value $\left(d=\delta^{2} \mathrm{H}-8 \delta^{18} \mathrm{O}\right)$ [49] was around $18 \%$, as compared to the value of $12 \% 0-15 \%$ in the lower altitudes (Table 3). In general, evaporation decreases and moisture recycling increases the deuterium excess $[50,51]$. In mountainous areas, moisture recycling could contribute to additional moisture with high deuterium excess value for precipitation $[50,52]$, resulting in high deuterium excess in spring water at higher altitudes.

In most cases, carbonate rocks have higher contents of strontium but lower ${ }^{87} \mathrm{Sr} /{ }^{86} \mathrm{Sr}$ as compared to strontium derived from silicate rocks with lower contents of strontium and higher ${ }^{87} \mathrm{Sr} /{ }^{86} \mathrm{Sr}$ [53]. Marine carbonate commonly has an ${ }^{87} \mathrm{Sr} /{ }^{86} \mathrm{Sr}$ value of less than 0.710 . Groundwater flowing through carbonate aquifers will more readily reach high concentration levels of $\mathrm{Sr}^{2+}$, resulting in fluids with low ${ }^{87} \mathrm{Sr} /{ }^{86} \mathrm{Sr}$ [53]. This contrasts with silicate groundwaters that tend to have higher ${ }^{87} \mathrm{Sr} /{ }^{86} \mathrm{Sr}$ and lower concentrations of $\mathrm{Sr}^{2+}$. In Guizhou, the ${ }^{87} \mathrm{Sr} /{ }^{86} \mathrm{Sr}$ ratio for carbonate rocks (including calcite and dolomite) could range from 0.7075 to 0.7100 [54]. Meanwhile, the results of previous studies show that $\mathrm{Sr}^{2+}$ originating from weathering of silicate rocks commonly has an ${ }^{87} \mathrm{Sr}^{186} \mathrm{Sr}$ ratio higher than $0.7150[55,56]$. The concentrations of $\mathrm{Sr}^{2+}$ in shallow groundwater ranged from $0.01 \mathrm{mg} / \mathrm{L}$ to $1.97 \mathrm{mg} / \mathrm{L}$, with an average of $0.37 \mathrm{mg} / \mathrm{L}$ (Table 3). Figure 5 shows the relationship between $1 / \mathrm{Sr}^{2+}$ and ${ }^{87} \mathrm{Sr} /{ }^{86} \mathrm{Sr}$ (Figure 5(a)) and the relationship between $\mathrm{Mg}^{2+} \mathrm{Ca}^{2+}$ and ${ }^{87} \mathrm{Sr} /{ }^{86} \mathrm{Sr}$ (Figure 5(b)) for spring water. Generally, when $\mathrm{Sr}^{2+}$ concentration decreased (i.e., $1 / \mathrm{Sr}^{2+}$ increased), the ${ }^{87} \mathrm{Sr} /{ }^{86} \mathrm{Sr}$ value increased. When the endmembers for limestone, dolomite, and silicate in Guizhou 
TABLE 2: Geochemical composition of spring water (mg/L).

\begin{tabular}{|c|c|c|c|c|c|c|c|c|c|c|c|c|c|c|c|c|}
\hline No. & Sample & $T\left({ }^{\circ} \mathrm{C}\right)$ & $\mathrm{pH}$ & $\mathrm{EC}(\mu \mathrm{s} / \mathrm{cm})$ & ORP $(\mathrm{mV})$ & TDS & $\mathrm{Cl}^{-}$ & $\mathrm{SO}_{4}{ }^{2-}$ & $\mathrm{HCO}_{3}^{-}$ & $\mathrm{F}^{-}$ & $\mathrm{NO}_{3}^{-}$ & $\mathrm{NH}_{4}^{+}$ & $\mathrm{Na}^{+}$ & $\mathrm{K}^{+}$ & $\mathrm{Mg}^{2+}$ & $\mathrm{Ca}^{2+}$ \\
\hline 1 & XS2 & 15.5 & 8.07 & 350 & -14.9 & 213 & 1.0 & 36.6 & 210 & 0.09 & 2.8 & 0.11 & 0.1 & 0.7 & 22.3 & 43.7 \\
\hline 2 & XS3 & 16.6 & 7.76 & 398 & -26.3 & 235 & 0.8 & 48.5 & 215 & 0.13 & 2.4 & & 0.1 & 0.5 & 24.7 & 49.6 \\
\hline 3 & XS5 & 15.8 & 7.74 & 370 & -21.7 & 236 & 0.9 & 51.3 & 210 & 0.12 & 1.7 & & 0.1 & 0.5 & 24.9 & 50.3 \\
\hline 4 & XS6 & 16.3 & 7.92 & 247 & -31.5 & 155 & 0.9 & 15.6 & 168 & 0.08 & 2.9 & 0.21 & 0.1 & 0.6 & 18.0 & 32.2 \\
\hline 5 & XS25 & 18.0 & 7.25 & 152 & +0.2 & 88 & 0.8 & 16.3 & 78 & 0.12 & 0.2 & 0.06 & 2.1 & 1.5 & 1.6 & 26.4 \\
\hline 6 & XS4 & 19.0 & 8.13 & 276 & -45.1 & 162 & 1.0 & 15.2 & 178 & 0.10 & 4.6 & & 0.1 & 0.7 & 18.5 & 32.3 \\
\hline 7 & XS7 & 17.8 & 7.35 & 328 & -1.5 & 216 & 2.5 & 13.4 & 222 & 0.10 & 8.4 & 0.28 & 2.0 & 1.2 & 2.0 & 74.7 \\
\hline 8 & XS8 & 17.6 & 7.59 & 343 & -14.1 & 228 & 1.3 & 26.3 & 234 & 0.07 & 1.8 & 0.08 & 1.1 & 0.4 & 3.3 & 75.8 \\
\hline 9 & XS9 & 22.5 & 8.01 & 366 & -38.3 & 227 & 2.4 & 39.0 & 198 & 0.07 & 6.1 & & 1.8 & 0.6 & 5.4 & 71.9 \\
\hline 10 & XS24 & 15.2 & 7.93 & & -36.7 & 148 & 1.4 & 18.6 & 129 & 0.07 & 10.5 & 0.08 & 1.6 & 2.3 & 1.5 & 47.6 \\
\hline 11 & XS10 & 17.8 & 7.44 & 429 & & 277 & 1.4 & 50.4 & 249 & 0.08 & 5.5 & & 2.6 & 0.9 & 9.6 & 81.5 \\
\hline 12 & XS11 & 17.6 & 7.20 & 426 & +5.5 & 279 & 1.1 & 21.7 & 305 & 0.07 & $<0.05$ & 0.08 & 0.7 & 0.2 & 3.3 & 98.9 \\
\hline 13 & XS12 & 18.1 & 7.12 & 514 & +10.0 & 356 & 1.4 & 35.7 & 382 & 0.11 & 3.2 & 0.13 & 3.2 & 0.7 & 11.5 & 108.1 \\
\hline 14 & $\mathrm{XS1}$ & 23.1 & 8.10 & 277 & -46.0 & 165 & 0.8 & 18.2 & 173 & 0.07 & 0.2 & 0.11 & 0.1 & 0.3 & 2.2 & 55.9 \\
\hline 15 & XS13 & 18.0 & 6.62 & 160 & 37.6 & 95 & 5.0 & 29.8 & 38 & 0.07 & 11.8 & 0.18 & 4.0 & 3.0 & 7.3 & 15.0 \\
\hline 16 & XS14 & 21.6 & 8.15 & 397 & -50.4 & 228 & 2.9 & 37.5 & 207 & 0.30 & 4.5 & & 0.6 & 0.1 & 5.3 & 72.0 \\
\hline 17 & XS16 & 20.4 & 8.29 & 338 & -57.6 & 207 & 1.1 & 19.3 & 231 & 0.06 & 2.9 & & 0.1 & 0.3 & 24.9 & 42.7 \\
\hline 18 & XS17 & 18.1 & 7.66 & 426 & -22.2 & 287 & 7.6 & 53.6 & 146 & 0.16 & 63.9 & 0.08 & 5.0 & 0.8 & 6.9 & 76.0 \\
\hline 19 & XS18 & 17.8 & 7.67 & 415 & -22.9 & 259 & 1.6 & 18.6 & 288 & 0.13 & 3.4 & 0.07 & 0.1 & 0.9 & 13.8 & 76.4 \\
\hline 20 & XS21 & 20.5 & 7.09 & 31 & +11.6 & 16 & 0.4 & 6.3 & 8 & 0.00 & $<0.05$ & 0.17 & 1.4 & 0.7 & 0.9 & 1.7 \\
\hline 21 & XS20 & 21.4 & 8.19 & 210 & -50.4 & 130 & 0.9 & 30.2 & 108 & 0.21 & $<0.05$ & 0.09 & 5.2 & 0.6 & 5.0 & 33.7 \\
\hline 22 & XS22 & 17.7 & 6.39 & 87 & +49.9 & 53 & 2.7 & 15.0 & 30 & 0.08 & 3.3 & 0.08 & 6.8 & 0.1 & 2.9 & 6.7 \\
\hline 23 & XS23 & 18.7 & 7.39 & 549 & -6.0 & 368 & 2.9 & 76.8 & 310 & 0.16 & 7.5 & 0.07 & 6.0 & 0.7 & 13.4 & 103.3 \\
\hline
\end{tabular}

[54] were used, silicate weathering contributed partially to the input of $\mathrm{Sr}^{2+}$. However, no relationship was found between $\mathrm{NO}_{3}^{-}$concentration and $\mathrm{Sr}^{2+}$ concentration $\left(R^{2}=0.01\right), \mathrm{Mg}^{2+} / \mathrm{Ca}^{2+}$ ratio $\left(R^{2}=0.01\right)$, and ${ }^{87} \mathrm{Sr} /{ }^{86} \mathrm{Sr}$ ratio $\left(R^{2}=0.00\right)$ for spring waters, suggesting that the impact of lithology on $\mathrm{NO}_{3}{ }^{-}$concentration is limited.

Nitrate concentrations for spring samples ranged from undetected $(<0.05 \mathrm{mg} / \mathrm{L})$ to $63.9 \mathrm{mg} / \mathrm{L}$ with a median value of $3.2 \mathrm{mg} / \mathrm{L}$. $\mathrm{NH}_{4}{ }^{+}$concentrations for all spring water samples ranged from $0.06 \mathrm{mg} / \mathrm{L}$ to $0.28 \mathrm{mg} / \mathrm{L}$ with a median value of $0.08 \mathrm{mg} / \mathrm{L}$. The $\mathrm{NH}_{4}{ }^{+}$concentrations were significantly lower than those from rainfall $(1.25 \mathrm{mg} / \mathrm{L})$. Nitrite $\left(\mathrm{NO}_{2}{ }^{-}\right)$was not detected in any spring water sample. The $\delta^{15} \mathrm{~N}^{-} \mathrm{NO}_{3}{ }^{-}$for all spring water samples ranged from $+0.1 \%$ to $+7.5 \%$, while the $\delta^{18} \mathrm{O}-\mathrm{NO}_{3}{ }^{-}$ranged from $-4.7 \%$ o to $+4.2 \%$ o (Table 3 ).

4.3. Origin of Nitrate for Spring Water. According to the definition from Shand and Edmunds [57], the groundwater baseline quality is "The range of concentrations of a given element, isotope or chemical compound in solution, derived entirely from natural, geological, biological or atmospheric sources, under condition not perturbed by anthropogenic activity". In terms of $\mathrm{NO}_{3}{ }^{-}$, the baseline value can be determined using spring water samples from the upper stream, which are not influenced at all by anthropogenic activity (no. 1 to no. 15, Table 2). The median (50\%) and upper values for $\mathrm{NO}_{3}{ }^{-}$baseline level, calculated using SigmaPlot (version 10.0), were found to be $2.9 \mathrm{mg} / \mathrm{L}$ and $11.0 \mathrm{mg} / \mathrm{L}$. These values are consistent with the baseline value for $\mathrm{NO}_{3}$ (median value of $2-9 \mathrm{mg} / \mathrm{L}$ and upper value of $8.2-$ $14.4 \mathrm{mg} / \mathrm{L}$ ) in arid-semiarid northern China [58]. The natural baseline for nitrate is unlikely to be more than $9-13 \mathrm{mg} / \mathrm{L}$ in most temperate regions covered by forest or grassland [57, 59]. Based on the baseline level, $\mathrm{NO}_{3}{ }^{-}$concentrations in other springs were within the baseline level (from $<0.05$ to $7.5 \mathrm{mg} / \mathrm{L}$ ), except for spring sample XS17, which had an $\mathrm{NO}_{3}{ }^{-}$concentration of $63.9 \mathrm{mg} / \mathrm{L}$; it was affected by anthropogenic activity.

Potential origins of $\mathrm{NO}_{3}{ }^{-}$, with $\mathrm{NO}_{3}{ }^{-}$concentrations less than the upper baseline level in the study area, are (1) direct $\mathrm{NO}_{3}{ }^{-}$input from rainfall, because rainfall has an average concentration of $2.59 \mathrm{mg} / \mathrm{L}$; (2) $\mathrm{NH}_{4}^{+}$from rainfall, because it has an average concentration of $1.25 \mathrm{mg} / \mathrm{L} \mathrm{NH}_{4}{ }^{+}$while concentrations of the latter in groundwater were less than $0.28 \mathrm{mg} / \mathrm{L}$, suggesting that the nitrification of rainfall $\mathrm{NH}_{4}^{+}$ could potentially contribute $\mathrm{NO}_{3}{ }^{-}$to groundwater; and (3) $\mathrm{NH}_{4}{ }^{+}$from soil nitrogen, which is a common source of groundwater $\mathrm{NO}_{3}^{-}[19,21]$. Denitrification, however, is a multistep process involving various nitrogen oxides (e.g., $\mathrm{N}_{2} \mathrm{O}, \mathrm{NO}$ ) as intermediate compounds resulting from a biologically mediated reduction of nitrate to $\mathrm{N}_{2}$ [19]. This process would decrease $\mathrm{NO}_{3}{ }^{-}$concentration and increase $\delta^{15} \mathrm{~N}$ and $\delta^{18} \mathrm{O}$ in the residual $\mathrm{NO}_{3}{ }^{-}$by a factor of $2: 1[19,48,60]$.

When rainfall recharges springs, the enrichment factor (f) (evapotranspiration from rainfall to the spring) is 
TABLE 3: Strontium and nitrate concentration and isotopic compositions for spring waters.

\begin{tabular}{|c|c|c|c|c|c|c|c|c|}
\hline Sample & $\mathrm{Sr}^{2+}(\mathrm{mg} / \mathrm{L})$ & ${ }^{87} \mathrm{Sr} /{ }^{86} \mathrm{Sr}$ & $\mathrm{NO}_{3}{ }^{-}(\mathrm{mg} / \mathrm{L})$ & $\delta^{15} \mathrm{~N}-\mathrm{NO}_{3}{ }^{-}(\% \mathrm{o})$ & $\delta^{18} \mathrm{O}-\mathrm{NO}_{3}^{-}(\%$ ) & $\delta^{18} \mathrm{O}-\mathrm{H}_{2} \mathrm{O}(\% \mathrm{o})$ & $\delta^{2} \mathrm{H}-\mathrm{H}_{2} \mathrm{O}(\% \mathrm{o})$ & $d(\% 0)$ \\
\hline $\mathrm{XS}-2$ & 0.76 & 0.709168 & 2.8 & +3.2 & -2.5 & -8.1 & -47.3 & 17.6 \\
\hline XS-3 & 0.91 & & 2.4 & +2.5 & -0.3 & -8.2 & -47.3 & 18.3 \\
\hline XS-5 & 1.04 & & 1.7 & +2.7 & -0.6 & -8.2 & -47.7 & 17.8 \\
\hline XS-6 & 0.10 & & 2.9 & & & -7.6 & -44.3 & 16.5 \\
\hline XS-25 & 0.13 & 0.710342 & 0.2 & & & -7.9 & -45.5 & 17.6 \\
\hline XS-4 & 0.25 & & 4.6 & & & -7.7 & -44.4 & 17.4 \\
\hline XS-7 & 0.12 & 0.712219 & 8.4 & +6.6 & +4.2 & -7.1 & -43.8 & 12.6 \\
\hline XS-8 & 0.18 & 0.712023 & 1.8 & & & -7.0 & -40.6 & 15.2 \\
\hline XS-9 & 0.24 & & 6.1 & & & -6.8 & -38.9 & 15.9 \\
\hline XS-24 & 0.08 & 0.712827 & 10.5 & +6.2 & +0.2 & -7.2 & -39.4 & 17.9 \\
\hline XS-10 & 0.42 & 0.710713 & 5.5 & +4.7 & +1.3 & -7.6 & -45.0 & 16.1 \\
\hline XS-11 & 0.16 & 0.711593 & $<0.05$ & & & -6.4 & -37.4 & 14.1 \\
\hline XS-12 & 0.64 & 0.710368 & 3.2 & & & -7.1 & -42.1 & 15.0 \\
\hline XS-1 & 0.09 & 0.710581 & 0.2 & & & -6.8 & -39.5 & 15.2 \\
\hline XS-13 & 0.11 & & 11.8 & +7.5 & +2.3 & -6.8 & -40.0 & 14.5 \\
\hline XS-14 & 0.62 & & 4.5 & & & -6.5 & -36.8 & 15.0 \\
\hline XS-16 & 0.02 & 0.711683 & 2.9 & & & -7.6 & -43.9 & 16.8 \\
\hline XS-17 & 0.26 & 0.707968 & 63.9 & +2.2 & +1.1 & -6.8 & -41.4 & 13.2 \\
\hline XS-18 & 0.12 & 0.709651 & 3.4 & +5.7 & -4.7 & -6.9 & -40.5 & 14.4 \\
\hline XS-21 & 0.01 & 0.715097 & $<0.05$ & & & -6.9 & -40.0 & 14.8 \\
\hline XS-20 & 0.15 & 0.712698 & $<0.05$ & & & -7.3 & -42.2 & 16.1 \\
\hline XS-22 & 0.06 & 0.711773 & 3.3 & & & -6.1 & -36.2 & 12.2 \\
\hline XS-23 & 1.97 & 0.711113 & 7.5 & +0.1 & +0.2 & -7.2 & -43.9 & 13.9 \\
\hline
\end{tabular}

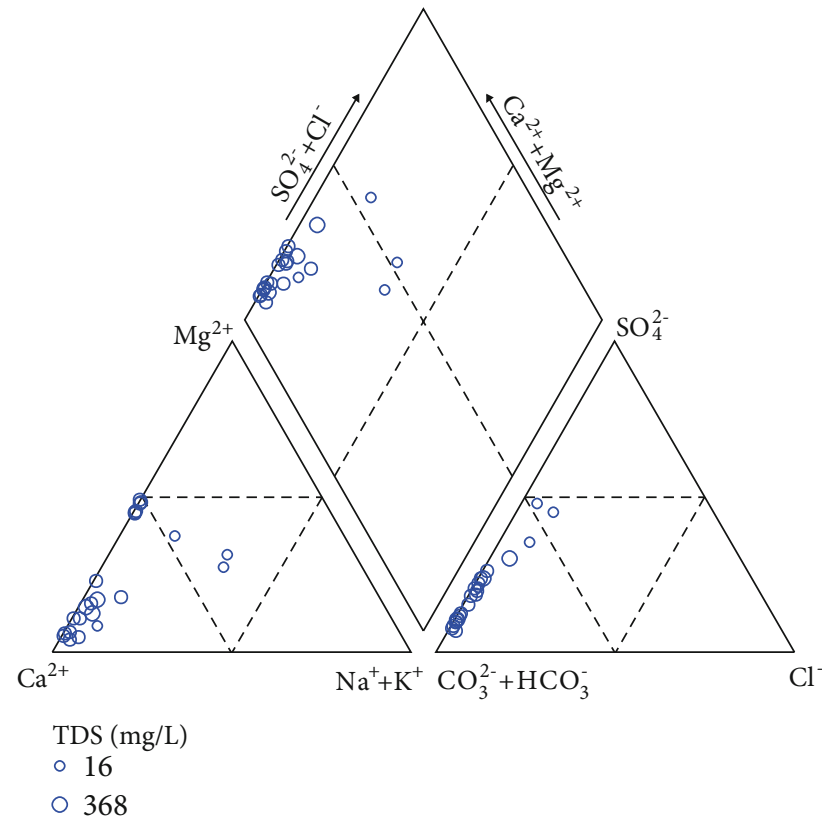

FIGURE 3: Piper diagram of spring water samples. The $\mathrm{HCO}_{3}{ }^{-} \mathrm{Ca}^{2+}$ and $\mathrm{HCO}_{3}{ }^{-} \mathrm{Ca}^{2+} \cdot \mathrm{Mg}^{2+}$ types were found to be dominant.

difficult to determine in a complicated hydrogeological system. However, the range of $2-5$ is used based on different sites with similar hydrogeological conditions in SW



FIgURE 4: Stable isotopic composition of springs. All springs lie around the LMWL, suggesting limited evaporation during recharge. LMWL for Zunyi: $\delta^{2} \mathrm{H}=7.89 \delta^{18} \mathrm{O}+11.95$ [46]; GMWL: $\delta^{2} \mathrm{H}=8 \delta^{18} \mathrm{O}+10[47]$.

China $[15,61,62]$. As the $\mathrm{NO}_{3}{ }^{-}$concentration in rainfall was $2.59 \mathrm{mg} / \mathrm{L}$, spring water should have $\mathrm{NO}_{3}{ }^{-}$concentrations of $5.2-13.0 \mathrm{mg} / \mathrm{L}$ if there is no loss during recharge. The value overlaps the spring $\mathrm{NO}_{3}{ }^{-}$value (from $<0.05$ to $11.8 \mathrm{mg} / \mathrm{L})$. However, plot of $\delta^{15} \mathrm{~N}^{-\mathrm{NO}_{3}}{ }^{-}$and $\delta^{18} \mathrm{O}-\mathrm{NO}_{3}{ }^{-}$ showed that the groundwater $\mathrm{NO}_{3}{ }^{-}$concentrations were similar to those of rainfall $\mathrm{NO}_{3}{ }^{-}$(Figure 6). The latter were less than $+4.2 \%$ o (Table 3 ) while the former were larger than $+24.9 \%$ and up to $+67.3 \%$ in Guiyang and Chongqing. Besides, groundwater $\mathrm{NO}_{3}{ }^{-}$concentrations were 


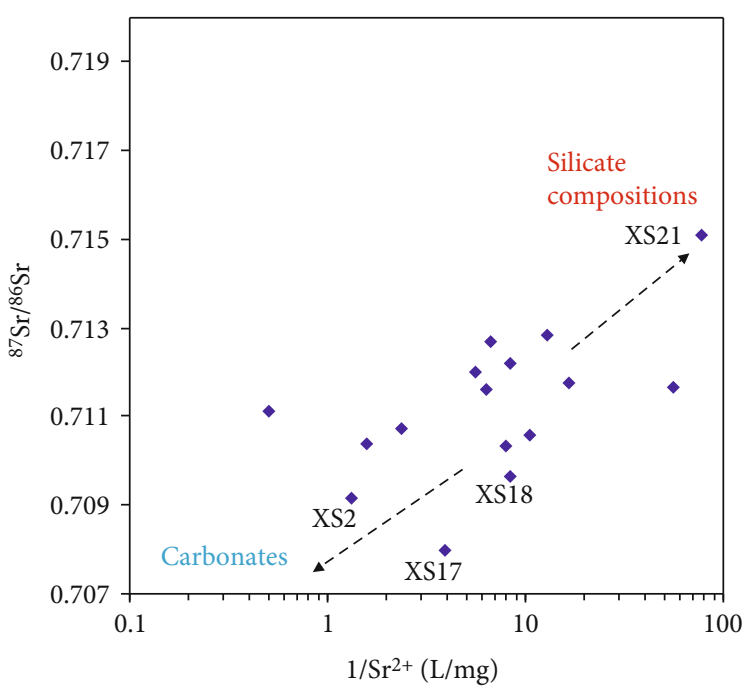

(a)

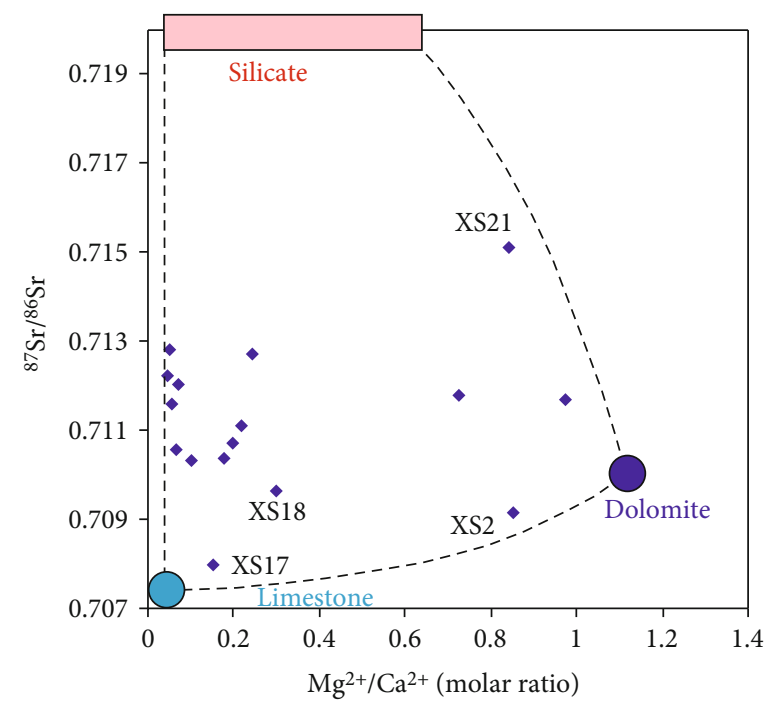

(b)

Figure 5: Relationship between ${ }^{87} \mathrm{Sr} /{ }^{86} \mathrm{Sr}$ and $1 / \mathrm{Sr}^{2+}$ (a) and between ${ }^{87} \mathrm{Sr} /{ }^{86} \mathrm{Sr}$ and $\mathrm{Mg}^{2+} / \mathrm{Ca}^{2+}$ (b). The three end-members of limestone, dolomite, and silicate are modified from [54].

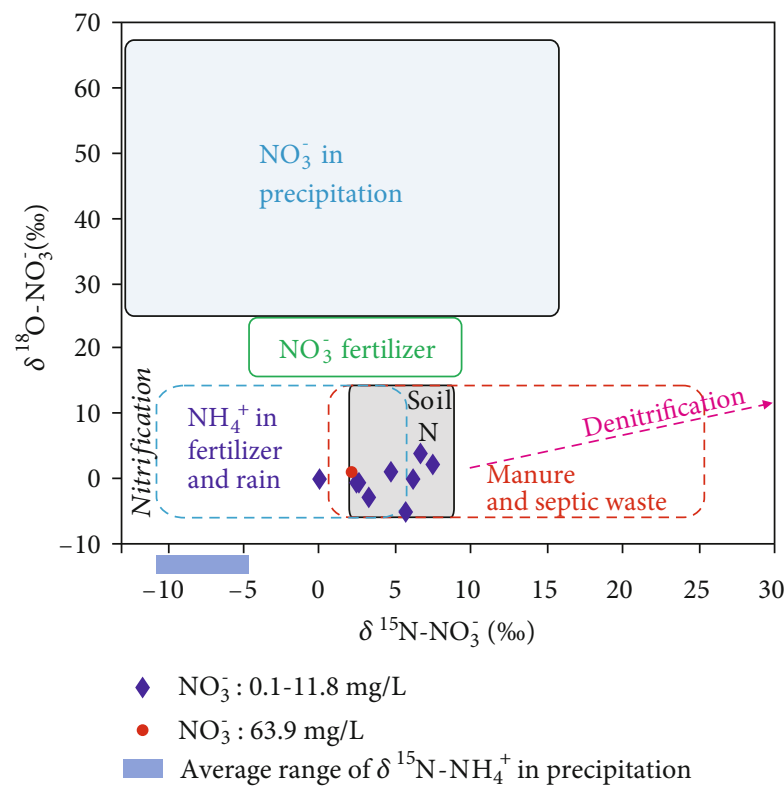

Figure 6: The relationship between $\delta^{15} \mathrm{~N}-\mathrm{NO}_{3}{ }^{-}$and $\delta^{18} \mathrm{O}-\mathrm{NO}_{3}{ }^{-}$for spring water. The range for $\delta^{15} \mathrm{~N}_{-} \mathrm{NO}_{3}{ }^{-}$and $\delta^{18} \mathrm{O}-\mathrm{NO}_{3}{ }^{-}$and average range for $\delta^{15} \mathrm{~N}^{-\mathrm{NH}_{4}+}$ for precipitation is from Guiyang and Chongqing. The schematic of typical ranges for other sources is from $[44,45]$.

lower compared with those in rain after during evapotranspiration (Figure 7(a)). Furthermore, groundwater $\mathrm{NO}_{3}{ }^{-}$enrichment was not caused by evapotranspiration (Figure $7(\mathrm{~b})$ ), because the $\mathrm{NO}_{3}{ }^{-} / \mathrm{Cl}^{-}$ratio would remain constant when $\mathrm{NO}_{3}{ }^{-}$increased. $\mathrm{NO}_{3}{ }^{-}$is the most usable form of nitrogen for plants [25]. Nitrate from atmospheric deposition is intensively cycled through the organic nitrogen pool in all watersheds [63] and can be taken up by plants [64]. The vegetation is dense in the study area.
Therefore, $\mathrm{NO}_{3}{ }^{-}$in spring water is not derived from rainfall $\mathrm{NO}_{3}{ }^{-}$.

The ammonium $\left(\mathrm{NH}_{4}^{+}\right)$concentration in spring water $(0.06-0.28 \mathrm{mg} / \mathrm{L})$ is significantly lower than that in rainfall $(1.25 \mathrm{mg} / \mathrm{L})$, suggesting that most $\mathrm{NH}_{4}{ }^{+}$in rainfall has been nitrified to $\mathrm{NO}_{3}{ }^{-}$during the recharge process $[11,13,15,65]$ :

$$
\mathrm{NH}_{4}{ }^{+}+2 \mathrm{O}_{2} \longrightarrow 2 \mathrm{H}^{+}+\mathrm{NO}_{3}{ }^{-}+\mathrm{H}_{2} \mathrm{O}
$$

where $1.00 \mathrm{mg} / \mathrm{L} \mathrm{NH}_{4}{ }^{+}$can produce $3.44 \mathrm{mg} / \mathrm{L} \mathrm{NO}_{3}{ }^{-}$. When $\mathrm{NH}_{4}{ }^{+}$concentration in rainfall is $1.25 \mathrm{mg} / \mathrm{L}$ and the enrichment factor is $2-5, \mathrm{NH}_{4}{ }^{+}$concentration for recharging spring would reach $2.50-6.25 \mathrm{mg} / \mathrm{L}$, potentially resulting in $8.6-$ $21.5 \mathrm{mg} / \mathrm{L} \mathrm{NO}_{3}{ }^{-}$in spring water. This value is similar to or higher than the $\mathrm{NO}_{3}{ }^{-}$concentration in spring water (from $<0.05$ to $11.8 \mathrm{mg} / \mathrm{L}$ ). Therefore, nitrification of $\mathrm{NH}_{4}{ }^{+}$in rainfall may be a potential source for spring $\mathrm{NO}_{3}{ }^{-}$. The average values of $\delta^{15} \mathrm{~N}-\mathrm{NH}_{4}{ }^{+}$for rainfall in adjacent areas (Guiyang and Chongqing) ranged from $-10.6 \%$ to $-4.7 \%$ o $[39,41$, 43]. There is isotopic fractionation for nitrogen, commonly a few per mill lighter [19] and up to $-35 \%$ o $[66,67]$ with respect to the ammonium source during nitrification of $\mathrm{NH}_{4}{ }^{+}$. However, it is difficult to accurately predict $\delta^{15} \mathrm{~N}$ $\mathrm{NO}_{3}{ }^{-}$from simple measurement of $\delta^{15} \mathrm{~N}-\mathrm{NH}_{4}{ }^{+}$due to complicated transformation processes and transformation rate $[10,44,68]$. If spring $\mathrm{NO}_{3}{ }^{-}$is derived from nitrification of rainfall $\mathrm{NH}_{4}{ }^{+}$, the $\delta^{15} \mathrm{~N}_{-} \mathrm{NO}_{3}{ }^{-}$of spring would have an average value of less than $-4.7 \%$. When the average value of

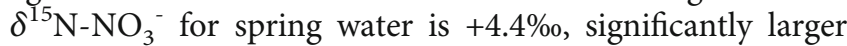
than that from nitrification of rainfall $\mathrm{NH}_{4}^{+}$(less than $-4.7 \%$ ), it can be concluded that spring $\mathrm{NO}_{3}{ }^{-}$is not derived from rainfall $\mathrm{NH}_{4}{ }^{+}$through nitrification. Therefore, rainfall $\mathrm{NH}_{4}{ }^{+}$can be said to have been consumed and contributes little to spring $\mathrm{NH}_{4}{ }^{+}$and $\mathrm{NO}_{3}{ }^{-}$. 


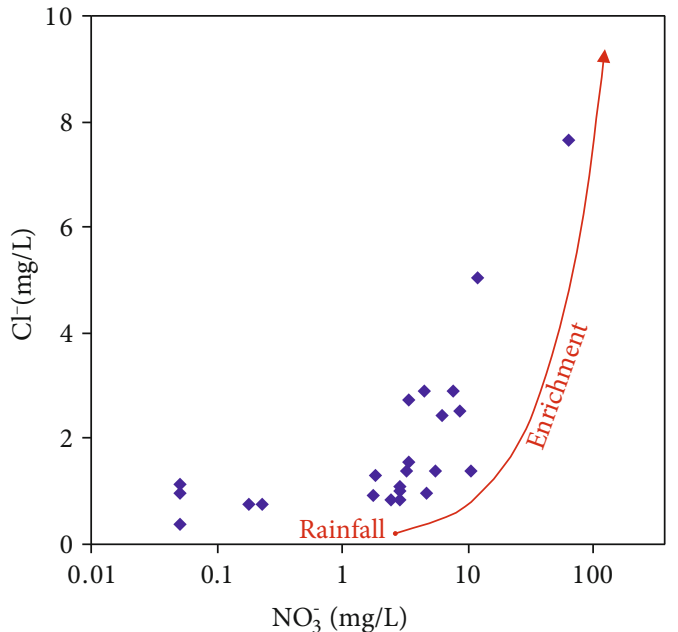

(a)



(b)

FIGURE 7: The relationship between $\mathrm{NO}_{3}{ }^{-}$and $\mathrm{Cl}^{-}$for spring and evapotranspiration line for rainfall (a) and between $\mathrm{NO}_{3}{ }^{-}$and $\mathrm{NO}_{3}{ }^{-} / \mathrm{Cl}^{-}(\mathrm{b})$. During evapotranspiration, $\mathrm{NO}_{3}{ }^{-} / \mathrm{Cl}^{-}$would remain constant.

Nitrification of soil nitrogen could be an important source for the natural groundwater system [69]. The $\delta^{15} \mathrm{~N}$ values of total soil $\mathrm{N}$ vary from $-10 \%$ to $+15 \%$, but typically range from $+2 \%$ to $+9 \%$ o $[19,45,70]$. During mineralization of soil $\mathrm{N}$ to $\mathrm{NH}_{4}^{+}$(sometimes it is called ammonification), there is very little isotopic fractionation for $\delta^{15} \mathrm{~N}$ [19]. However, the further nitrification process will result in a slightly lighter (few per mill) $\delta^{15} \mathrm{~N}$ for nitrate in $\mathrm{N}$-limited systems [19]. The $\delta^{15} \mathrm{~N}^{-N}{ }_{3}{ }^{-}$for spring water was within the range of $\mathrm{NO}_{3}{ }^{-}$derived from soil $\mathrm{N}$ nitrification (Figure 6). In addition, nitrate derived from nitrification should have $\delta^{18} \mathrm{O}$ $\mathrm{NO}_{3}{ }^{-}$between $-9 \%$ and $+11 \%$ as the $\mathrm{O}$ in $\mathrm{NO}_{3}{ }^{-}$is derived from $\mathrm{H}_{2} \mathrm{O}(2 / 3)$ with $\delta^{18} \mathrm{O}$ values in the normal range of $-25 \%$ to $+4 \%$ and from $\mathrm{O}_{2}(1 / 3)$ with $\delta^{18} \mathrm{O}$ of $+23.5 \%$ $[71,72]$. However, these values can vary due to changes in ammonium abundance and nitrification rates [10]. The $\delta^{15} \mathrm{~N}^{-\mathrm{NO}_{3}}{ }_{3}$ for spring water ranged from $+0.1 \%$ to $+7.5 \%$, while the $\delta^{18} \mathrm{O}_{-} \mathrm{NO}_{3}{ }^{-}$ranged from $-4.7 \%$ o to $+4.2 \%$, all within the acceptable range for nitrification of soil nitrogen (Figure 6). Therefore, nitrate from nitrification of soil nitrogen is a potential source for spring nitrate.

A weakly positive relationship was found between $\mathrm{NO}_{3}{ }^{-}$ concentration and $\delta^{15} \mathrm{~N}^{-\mathrm{NO}_{3}}{ }^{-}\left(\delta^{15} \mathrm{~N}=0.356 \mathrm{NO}_{3}{ }^{-}+2.22\right.$, $R^{2}=0.31$, suggesting that the increase in $\delta^{15}{\mathrm{~N}-\mathrm{NO}_{3}}^{-}$is not related to denitrification, which would result in a decrease in $\mathrm{NO}_{3}{ }^{-}$concentration. In addition, the ORP values ranged from -57.6 to $+49.9 \mathrm{mV}$ (Table 1 ) with an average value of $-16 \mathrm{mV}$. The absence of correlation for ORP and $\mathrm{NO}_{3}{ }^{-}$ suggests that denitrification process is limited in the study area.

Based on the aforementioned results, $\mathrm{NO}_{3}{ }^{-}$with concentration less than $12 \mathrm{mg} / \mathrm{L}$ in spring waters in the study area mainly originated from the nitrification of soil $\mathrm{N}$, rather than direct input of rainfall $\mathrm{NO}_{3}{ }^{-}$or nitrification of rain $\mathrm{NH}_{4}{ }^{+}$ (Figure 8 ). Although the latter two processes can potentially contribute up to $13.8-34.5 \mathrm{mg} / \mathrm{L} \mathrm{NO}_{3}{ }^{-}$in a spring, $\mathrm{NO}_{3}$ and $\mathrm{NH}_{4}^{+}$transformation could affect the fate of nitrate in this mountainous area affected by regional acid rain. In similar study areas in Guizhou Province, Li et al. [69] attributed the origin of $\mathrm{NO}_{3}{ }^{-}$with similar concentration and similar isotopic composition $\left({ }^{15} \mathrm{~N}-\mathrm{NO}_{3}{ }^{-}\right.$and $\left.\delta^{18} \mathrm{O}-\mathrm{NO}_{3}{ }^{-}\right)$to nitrification of soil $\mathrm{N}$. This study has provided isotopic evidence that rainfall input has contributed little to $\mathrm{NO}_{3}{ }^{-}$in spring waters.

For spring water XS17, which has been affected by anthropogenic activities, the $\mathrm{NO}_{3}^{-}$concentration was $63.9 \mathrm{mg} / \mathrm{L}$ with $\delta^{15} \mathrm{~N}^{-\mathrm{NO}_{3}}{ }_{3}$ value of $+2.2 \%$ and $\delta^{18} \mathrm{O}-\mathrm{NO}_{3}{ }^{-}$ value of $+1.1 \%$ (Figure 6 ). There are two potential sources: (1) nitrification of ammonium from fertilizer and (2) manure and septic wastewater. Based on field surveys, this spring water was found to be affected by distributed croplands. The infiltrating water or/and overflow may flow into the recharge area of the spring XS17. The high $\mathrm{NO}_{3}{ }^{-}$concentration is related to the use of ammonium fertilizers. $\mathrm{NO}_{3}{ }^{-}$from manure and septic waster would have higher $\delta^{15} \mathrm{~N}^{-} \mathrm{NO}_{3}{ }^{-}$ (typically $+7 \% 0-+25 \%$ ) value $[27,44,45,73]$. The $\delta^{15} \mathrm{~N}$ $\mathrm{NO}_{3}{ }^{-}$value of $+2.2 \%$ is significantly lower than that from manure and septic wastewater, suggesting that the spring XS17 with $\mathrm{NO}_{3}^{-}$concentration of $63.9 \mathrm{mg} / \mathrm{L}$ was derived from nitrification of ammonium fertilizers (Figure 6).

\section{Conclusions}

While some studies have considered the atmospheric input of nitrate to groundwater systems, this study shows that the direct input of rainfall nitrate and input through nitrification of rainfall ammonium contributes little to groundwater nitrate, even when nitrate and ammonium concentrations in rainfall are high. The inorganic nitrogen from rainfall is consumed, and groundwater nitrate is mainly derived from nitrification of soil nitrogen at the natural groundwater system. In the study area, the moisture recycling in higher altitudes could contribute to additional moisture, resulting in high deuterium excess in spring samples at higher altitudes. 




Figure 8: Conceptual model of the nitrogen cycle in the study area. Note: FE= enrichment factor.

The ${ }^{87} \mathrm{Sr} /{ }^{86} \mathrm{Sr}$ ratios show the chemical types of spring water are controlled by lithology. However, the impact of lithology and evapotranspiration on $\mathrm{NO}_{3}{ }^{-}$concentration is limited in the study area. This study helps understand the nitrogen cycle and trace groundwater nitrate sources.

\section{Data Availability}

The data used to support the findings of this study are included within the article.

\section{Conflicts of Interest}

The authors declare that there is no conflict of interest regarding the publication of this paper.

\section{Acknowledgments}

This work was supported by the National Natural Science Foundation of China (Grants 41672254 and 41877207), the Youth Innovation Promotion Association CAS (Grant 2018087), and a CAS scholarship to visit the University of Calgary (Grant 201825).

\section{References}

[1] J. N. Galloway and E. B. Cowling, "Reactive nitrogen and the world: 200 years of change,” Ambio, vol. 31, no. 2, pp. 64-71, 2002.

[2] D. Moncoulon, A. Probst, and J. P. Party, “Alteration, depots atmospheriques et prelevement par la vegetation : role dans la sensibilite des ecosystemes aux depots acides et charges critiques.," Comptes Rendus Geoscience, vol. 336, no. 16, pp. 1417-1426, 2004.

[3] V. Majer, P. Kram, and J. B. Shanley, "Rapid regional recovery from sulfate and nitrate pollution in streams of the western Czech Republic - comparison to other recovering areas," Environmental Pollution, vol. 135, no. 1, pp. 17-28, 2005.
[4] F. Oulehle, K. Jiri, C. Tomas et al., "Predicting sulphur and nitrogen deposition using a simple statistical method," Atmospheric Environment, vol. 140, pp. 456-468, 2016.

[5] R. Vet, R. S. Artz, S. Carou et al., "A global assessment of precipitation chemistry and deposition of sulfur, nitrogen, sea salt, base cations, organic acids, acidity and $\mathrm{pH}$, and phosphorus," Atmospheric Environment, vol. 93, pp. 3-100, 2014.

[6] W. Wang, W. Zhang, X. Hong, and Q. Shi, "Study on factors related to acidity of rain water in China," China Environmental Science, vol. 13, no. 1, pp. 401-407, 1993.

[7] Z. Li, "Relation between ion concentration and $\mathrm{pH}$ in precipitation in number of Chinese cities," Acta Scientiae Circumstantiae, vol. 19, no. 3, pp. 303-306, 1999.

[8] Ministry of Environmental Protection of the People's Republic of China, China Environmental Bulletin in 2014, Beijing, China, 2015, http://www.mee.gov.cn/hjzl/zghjzkgb/lnzghjzkgb/.

[9] EANET-Acid Deposition Monitoring Network in East Asia, "EANET data on the acid deposition in the East Asian region," 2019, https://www.eanet.asia.

[10] B. Mayer, S. M. Bollwerk, T. Mansfeldt, B. Hütter, and J. Veizer, "The oxygen isotope composition of nitrate generated by nitrification in acid forest floors," Geochimica et Cosmochimica Acta, vol. 65, no. 16, pp. 2743-2756, 2001.

[11] N. van Breemen, P. A. Burrough, E. J. Velthorst et al., "Soil acidification from atmospheric ammonium sulphate in forest canopy throughfall," Nature, vol. 299, no. 5883, pp. 548-550, 1982.

[12] R. W. Howarth, "The nitrogen cycle," in Encyclopedia of Global Environmental Change, The Earth System: Biological and Ecological Dimensions of Global Environmental Change, H. A. Mooney and J. G. Canadell, Eds., vol. 2, pp. 429-435, Wiley, Chichester, UK, 2002.

[13] C. A. J. Appelo and D. Postma, Geochemistry, Groundwater and Pollution (2nd Edition), A.A. Balkema Publishers, Amsterdam, the Netherlands, 2005.

[14] K. Semhi, P. A. Suchet, N. Clauer, and J. L. Probst, "Impact of nitrogen fertilizers on the natural weathering-erosion processes and fluvial transport in the Garonne basin," Applied Geochemistry, vol. 15, no. 6, pp. 865-878, 2000. 
[15] T. Huang, Y. Fan, Y. Long, and Z. Pang, "Quantitative calculation for the contribution of acid rain to carbonate weathering," Journal of Hydrology, vol. 568, pp. 360-371, 2019.

[16] P. Matson, K. A. Lohse, and S. J. Hall, "The globalization of nitrogen deposition: consequences for terrestrial ecosystems," Ambio, vol. 31, no. 2, pp. 113-119, 2002.

[17] D. E. Canfield, A. N. Glazer, and P. G. Falkowski, "The evolution and future of Earth's nitrogen cycle," Science, vol. 330, no. 6001, pp. 192-196, 2010.

[18] World Health Organization, Guidelines for Drinking-Water Quality (Fourth Edition), WHO Press, Geneva, Switzerland, 2011.

[19] C. Kendall and R. Aravena, "Nitrate isotopes in groundwater systems," in Environmental Tracers in Subsurface Hydrology, P. G. Cook and A. L. Herczeg, Eds., Kluwer Academic Publishers, Boston, 2000.

[20] L. Yuan, Z. Pang, and T. Huang, "Integrated assessment on groundwater nitrate by unsaturated zone probing and aquifer sampling with environmental tracers," Environmental Pollution, vol. 171, pp. 226-233, 2012.

[21] S. L. Li, C. Q. Liu, J. Li et al., "Assessment of the sources of nitrate in the Changjiang River, China using a nitrogen and oxygen isotopic approach," Environmental Science \& Technology, vol. 44, no. 5, pp. 1573-1578, 2010.

[22] Z. Kovač, Z. Nakić, J. Barešić, and J. Parlov, "Nitrate origin in the Zagreb aquifer system," Geofluids, vol. 2018, Article ID 2789691, 15 pages, 2018.

[23] W. Durka, E. D. Schulze, G. Gebauer, and S. Voerkelius, "Effects of forest decline on uptake and leaching of deposited nitrate determined from $15 \mathrm{~N}$ and $18 \mathrm{O}$ measurements," Nature, vol. 372, no. 6508, pp. 765-767, 1994.

[24] D. A. J. Barry, D. Goorahoo, and M. J. Goss, "Estimation of nitrate concentrations in groundwater using a whole farm nitrogen budget," Journal of Environmental Quality, vol. 22, no. 4, pp. 767-775, 1993.

[25] F. T. Wakida and D. N. Lerner, "Non-agricultural sources of groundwater nitrate: a review and case study," Water Research, vol. 39, no. 1, pp. 3-16, 2005.

[26] M. N. Almasri and J. J. Kaluarachchi, "Modeling nitrate contamination of groundwater in agricultural watersheds," Journal of Hydrology, vol. 343, no. 3-4, pp. 211-229, 2007.

[27] B. Deutsch, M. Mewes, I. Liskow, and M. Voss, "Quantification of diffuse nitrate inputs into a small river system using stable isotopes of oxygen and nitrogen in nitrate," Organic Geochemistry, vol. 37, no. 10, pp. 1333-1342, 2006.

[28] F. Liu, S. Xie, P. Xie, and W. Zhang, "Analysis on characteristics of landscape pattern of land use in Xishui County of Guizhou Province," Tianjin Agricultural Sciences, vol. 21, no. 12, pp. 84-88, 2015.

[29] D. Yang, S. Liu, Y. Shan et al., "Fracture characteristics of shale in Upper Ordovician-Lower Silurian in Xishui area, southeast of Sichuan Basin, China," Journal of Chengdu University of Technology, vol. 40, pp. 543-553, 2013.

[30] Guizhou Geological Bureau, The Geology Map of Tongzi in Guizhou (1:200,000), China Geology Map Press, Beijing, China, 1978.

[31] PLA's 00932 Unit, The Integration Hydrogeology Map of Tongzi in Guizhou (1:200,000), China Geology Map Press, Beijing, China, 1978.

[32] D. M. Sigman, K. L. Casciotti, M. Andreani, C. Barford, M. Galanter, and J. K. Böhlke, "A bacterial method for the nitrogen isotopic analysis of nitrate in seawater and freshwater," Analytical Chemistry, vol. 73, no. 17, pp. 4145-4153, 2001.

[33] K. L. Casciotti, D. M. Sigman, M. Galanter, J. Hastings, K. Böhlke, and A. Hilkert, "Measurement of the oxygen isotopic composition of nitrate in seawater and freshwater using the denitrifier method," Analytical Chemistry, vol. 74, no. 19, pp. 4905-4912, 2002.

[34] L. Li, "Pollution characteristics and origin of acid rain in Zunyi," Guizhou Environmental Science \& Technology, vol. 11, no. 4, pp. 6-9, 2005.

[35] C. Zhao, J. Yu, X. Li, and S. Shuai, "The characteristics of acid rain in Zunyi," Journal of Guizhou Meteorology, vol. 33, no. 3, pp. 16-19, 2009.

[36] N. Luo, L. Zeng, Y. Wu, and H. Lyu, "The characteristics of acid rain in Guiyang," Journal of Guizhou Meteorology, vol. 37, no. 4, pp. 18-23, 2013.

[37] H. Xiao, H. Xiao, and Y. Wang, "Chemical characteristics and source apportionment of precipitation in Guiyang," China Environmental Science, vol. 30, pp. 1590-1596, 2010.

[38] H. Zhang, S. Yu, S. He, Q. Liu, and Y. Li, "Analysis on the chemical characteristics of the atmospheric precipitation in Guilin," Carsologica Sinica, vol. 31, pp. 289-295, 2012.

[39] X. Liu, H. Xiao, H. Xiao et al., "Stable isotope analyses of precipitation nitrogen sources in Guiyang, southwestern China," Environmental Pollution, vol. 230, pp. 486-494, 2017.

[40] S. L. Li, C. Q. Liu, J. Hu, J. Li, and N. An, "The characteristics of $\mathrm{N}$ and $\mathrm{O}$ isotopes for inorganic $\mathrm{N}$ from rainfall in Guiyang," Bulletin of Mineralogy, Petrology and Geochemistry, vol. 25, pp. 57-59, 2006.

[41] H. Xiao, H. Xiao, A. Long, and Y. Wang, "Who controls the monthly variations of $\mathrm{NH}_{4}^{+}$nitrogen isotope composition in precipitation?," Atmospheric Environment, vol. 54, pp. 201206, 2012.

[42] H. Xiao and C. Q. Liu, "Sources of nitrogen and sulfur in wet deposition at Guiyang, Southwest China," Atmospheric Environment, vol. 36, no. 33, pp. 5121-5130, 2002.

[43] X. Li, H. Masuda, K. Koba, and H. Zeng, "Nitrogen isotope study on nitrate-contaminated groundwater in the Sichuan Basin, China," Water, Air, \& Soil Pollution, vol. 178, no. 1-4, pp. 145-156, 2007.

[44] C. Kendall, "Tracing sources and cycling of nitrate in catchments," in Isotope Tracers in Catchment Hydrology, C. Kendall and J. J. McDonnell, Eds., pp. 519-576, Elsevier, Amsterdam, Netherlands, 1998.

[45] D. Xue, J. Botte, B. De Baets et al., "Present limitations and future prospects of stable isotope methods for nitrate source identification in surface- and groundwater," Water Research, vol. 43, no. 5, pp. 1159-1170, 2009.

[46] IAEA/WMO, Global Network of Isotopes in Precipitation, 2019, The GNIP Database. http://www.iaea.org/water.

[47] H. Craig, "Isotopic variations in meteoric waters," Science, vol. 133, no. 3465, pp. 1702-1703, 1961.

[48] I. D. Clark and P. Fritz, Environmental Isotopes in Hydrogeology, Lewis, Boca Raton, Florida, 1997.

[49] W. Dansgaard, "Stable isotopes in precipitation," Tellus, vol. 16, no. 4, pp. 436-468, 1964.

[50] K. Froehlich, M. Kralik, W. Papesch, D. Rank, and H. Scheifinger, "Deuterium excess in precipitation of Alpine regions - moisture recycling," Isotopes in Environmental and Health Studies, vol. 44, no. 1, pp. 61-70, 2008. 
[51] T. Huang and Z. Pang, "The role of deuterium excess in determining the water salinisation mechanism: a case study of the arid Tarim River Basin, NW China," Applied Geochemistry, vol. 27, no. 12, pp. 2382-2388, 2012.

[52] Z. Pang, Y. Kong, K. Froehlich et al., "Processes affecting isotopes in precipitation of an arid region," Tellus B: Chemical and Physical Meteorology, vol. 63, no. 3, pp. 352-359, 2011.

[53] R. H. McNutt, "Strontium isotopes," in Environmental Tracers in Subsurface Hydrology, P. G. Cook and A. L. Herczeg, Eds., pp. 233-260, Kluwer, Boston, 2000.

[54] G. Han and C. Q. Liu, "Water geochemistry controlled by carbonate dissolution: a study of the river waters draining karstdominated terrain, Guizhou Province, China," Chemical Geology, vol. 204, no. 1-2, pp. 1-21, 2004.

[55] P. Negrel, C. J. Allegre, B. Dupre, and E. Lewin, "Erosion sources determined by inversion of major and trace element ratios and strontium isotopic ratios in river water: the Congo Basin case," Earth and Planetary Science Letters, vol. 120, no. 1-2, pp. 59-76, 1993.

[56] S. J. Goldstein and S. B. Jacobsen, "The Nd and Sr isotopic systematics of river-water dissolved material: Implications for the sources of $\mathrm{Nd}$ and $\mathrm{Sr}$ in seawater," Chemical Geology, vol. 66, no. 3-4, pp. 245-272, 1987.

[57] P. Shand and W. M. Edmunds, "The baseline inorganic chemistry of European groundwaters," in Natural Groundwater Quality, W. M. Edmunds and P. Shand, Eds., pp. 22-58, Blackwell, New York, NY, USA, 2008.

[58] T. Huang, Z. Pang, and L. Yuan, "Nitrate in groundwater and the unsaturated zone in (semi)arid northern China: baseline and factors controlling its transport and fate," Environmental Earth Sciences, vol. 70, no. 1, pp. 145-156, 2013.

[59] D. K. Mueller and D. R. Helsel, "Nutrients in the Nation's Waters-Too Much of a Good Thing?," Circular, vol. 1136, no. 24, 1996.

[60] R. Aravena, M. L. Evans, and J. A. Cherry, "Stable isotopes of oxygen and nitrogen in source identification of nitrate from septic systems," Ground Water, vol. 31, no. 2, pp. 180-186, 1993.

[61] S. L. Li, D. Calmels, G. Han, J. Gaillardet, and C. Q. Liu, "Sulfuric acid as an agent of carbonate weathering constrained by $\delta^{13}$ CDIC: Examples from Southwest China," Earth and Planetary Science Letters, vol. 270, no. 3-4, pp. 189-199, 2008.

[62] C. Q. Liu, Y. K. Jiang, F. X. Tao, Y. C. Lang, and S. L. Li, "Chemical weathering of carbonate rocks by sulfuric acid and the carbon cycling in Southwest China," Geochimica, vol. 37, pp. 404-414, 2008.

[63] B. Mayer, E. W. Boyer, C. Goodale et al., "Sources of nitrate in rivers draining sixteen watersheds in the northeastern U.S.: Isotopic constraints," Biogeochemistry, vol. 57, no. 1, pp. 171-197, 2002.

[64] R. F. Spalding and M. E. Exner, "Occurrence of nitrate in groundwater-a review," Journal of Environmental Quality, vol. 22, no. 3, pp. 392-402, 1993.

[65] Z. Shen, Y. Zhu, and Y. Zhong, Hydrogeochemistry, Geological Publishing House, Beijing, 1993.

[66] C. C. Delwiche and P. L. Steyn, "Nitrogen isotope fractionation in soils and microbial reactions," Environmental Science \& Technology, vol. 4, no. 11, pp. 929-935, 1970.

[67] A. Mariotti, F. Mariotti, N. Amarger et al., "Fractionnements isotopique de I'azote atmospheric par les plantes," Physiology Vegetation, vol. 18, pp. 163-181, 1980.
[68] Z. Pang, L. Yuan, T. Huang, Y. Kong, J. Liu, and Y. Li, "Impacts of human activities on the occurrence of groundwater nitrate in an alluvial plain: a multiple isotopic tracers approach," Journal of Earth Science, vol. 24, no. 1, pp. 111-124, 2013.

[69] S. L. Li, C. Q. Liu, J. Li et al., "Evaluation of nitrate source in surface water of southwestern China based on stable isotopes," Environmental Earth Sciences, vol. 68, no. 1, pp. 219-228, 2013.

[70] R. Amundson, A. T. Austin, E. A. G. Schuur et al., "Global patterns of the isotopic composition of soil and plant nitrogen," Global Biogeochemical Cycles, vol. 17, no. 1, p. 1031, 2003.

[71] P. Kroopnick and H. Craig, "Atmospheric oxygen: isotopic composition and solubility fractionation," Science, vol. 175, no. 4017, pp. 54-55, 1972.

[72] T. C. Hollocher, "Source of the oxygen atoms of nitrate in the oxidation of nitrite by Nitrobacter agilis and evidence against a P-O-N anhydride mechanism in oxidative phosphorylation," Archives of Biochemistry and Biophysics, vol. 233, no. 2, pp. 721-727, 1984.

[73] P. Yang, Y. Li, C. Groves, and A. Hong, "Coupled hydrogeochemical evaluation of a vulnerable karst aquifer impacted by septic effluent in a protected natural area," Science of the Total Environment, vol. 658, pp. 1475-1484, 2019. 

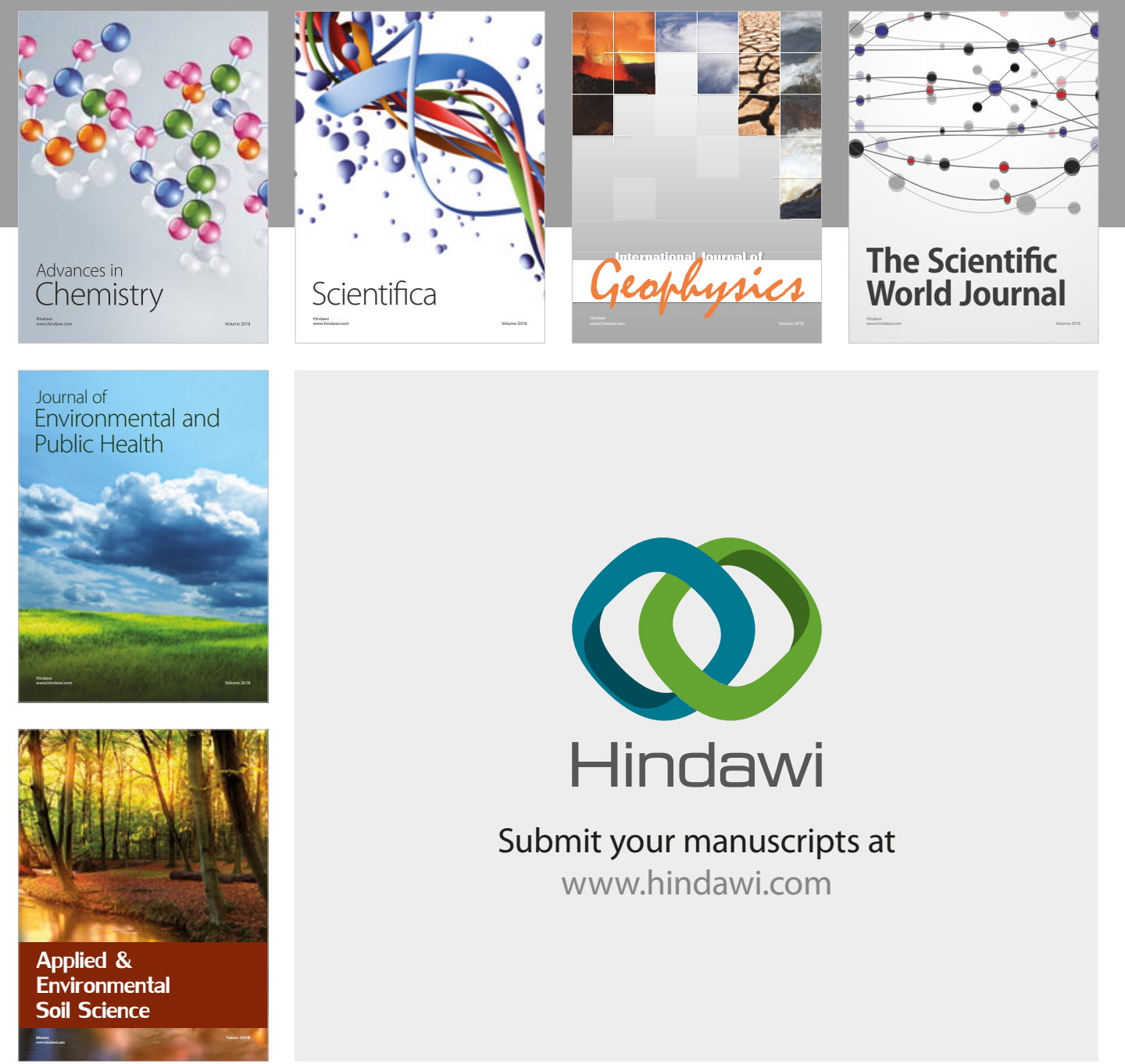

The Scientific

\section{World Journal}
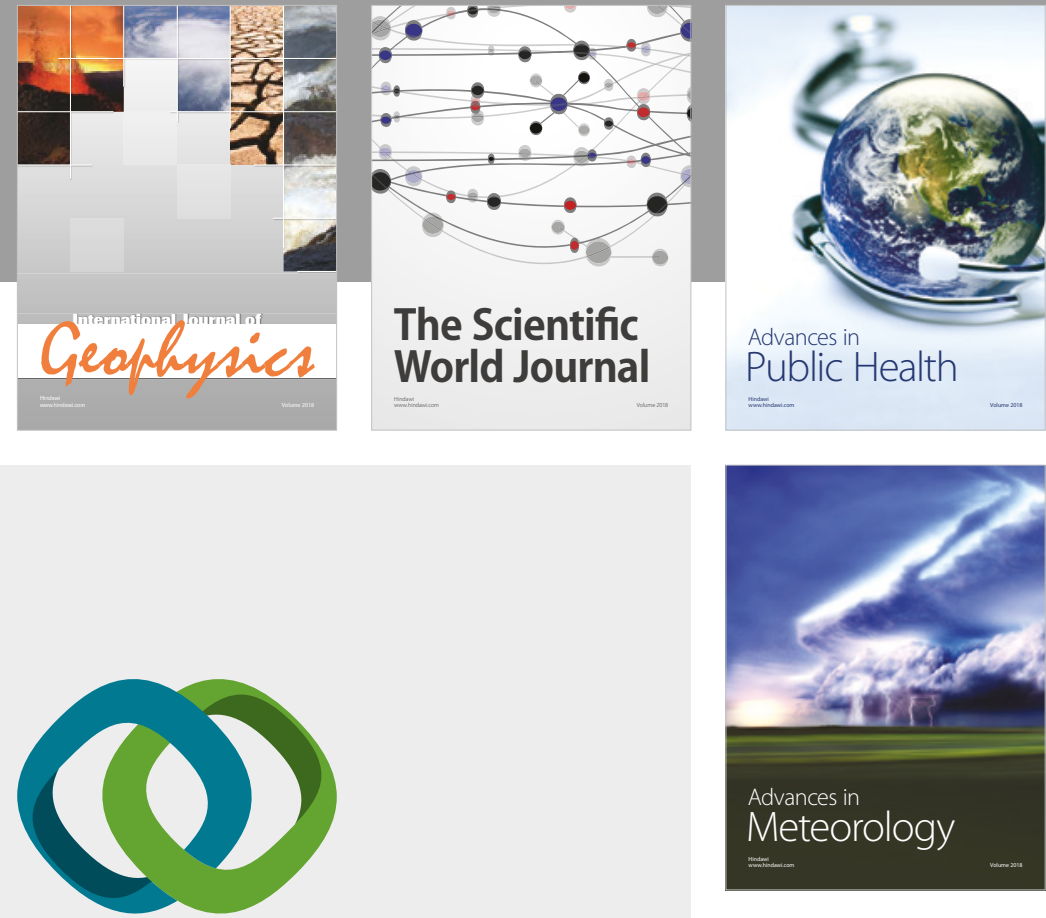

Advan

Public Health

\section{Hindawi}

Submit your manuscripts at

www.hindawi.com
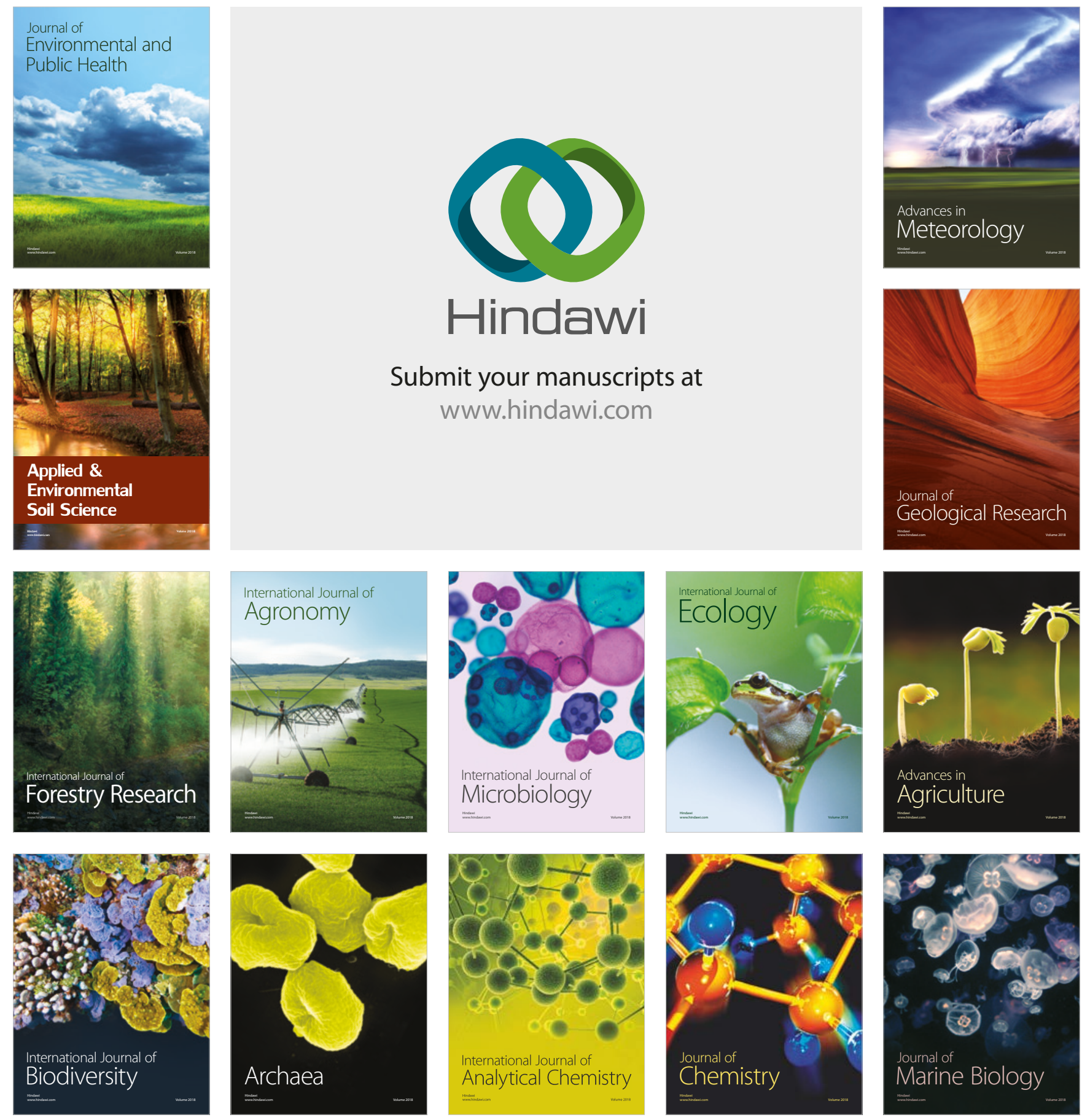